Diabetologia 10, 37-44 (1973)

(c) by Springer-Verlag 1973

\title{
Fine Structure of Rat Islet Cell Tumors Induced by Streptozotocin and Nicotinamide****
}

\author{
B. W. Volk, K.F. Wellmann and P. Brancato \\ Isaac Albert Research Institute of the Kingsbrook Jewish Medical Center, Brooklyn, New York 11203, U.S.A.
}

Received: June 13, 1973, and in revised form: September 27, 1973

\begin{abstract}
Summary. Young male Holtzman rats were injected intravenously with $50 \mathrm{mg} / \mathrm{kg}$ of streptozotocin, preceded and followed by a single intraperitoneal injection of 350 $\mathrm{mg} / \mathrm{kg}$ of nicotinamide, according to the method of Rakieten et al. [16]. After 245 to 323 days, 27 pancreatic islet cell tumors measuring up to $0.6 \mathrm{~cm}$ were demonstrable in 20 of 41 rats so treated; they were solitary in 15 and multiple (two or three neoplasms each) in five animals. It was not possible to distinguish between tumorbearing and tumor-free rats on the basis of periodic blood sugar determinations and serum insulin assays. Mean insulin concentration in grossly tumor-free pancreatic specimens was 0.661 units of insulin/g of wet tissue, but amounted to 5.385 units/g in specimens containing tumor. The islet cell tumors were rounded and well delineated. They were located in all parts of the pancreas. In general,
\end{abstract}

their cells stained deeply with aldehyde-fuchsin. Ultrastructurally, most tumors consisted of well granulated $B$ cells. A or D cells were not encountered while occasional EC cells were identified. Nucleoli were frequently prom. inent. Some necrotic B cells and others with few or unusually small secretory granules were present. Extravasated erythrocytes as well as hemosiderin deposits were seen in many tumors, and tumor cell particles were occasionally noted within the lumina of capillaries. Distant metastases were not demonstrable in this group of animals.

Key words: Experimental insulinoma, experimental nesidioblastoma, experimental islet cell tumor in rats, immunoreactive insulin content of experimental insulinomas, ultrastructure of experimental insulinomas.
Streptozotocin is a naturally occurring nitrosourea compound that exerts antibiotic, oncogenic, oncolytic and diabetogenic activities, the latter mediated by the selective destruction of the beta cells of the pancreatic islets. It has been shown that the diabetogenic action of streptozotocin can be prevented by nicotinamide in the rat and in other animal species [19]. In the course of a long-term light microscopic study in male Holtzman rats on the repression by nicotinamide of the renal oncogenic action of streptozotocin, Rakieten et al. [16] have recently observed that 18 of $28(64 \%)$ animals developed pancreatic islet cell tumors under the combined influence of these two agents. These tumors first became apparent on day 226 of their study, but most of them were detected much later, i.e., in rats sacrificed on days 438 to 547. Only one islet cell tumor was observed among 26 animals treated with streptozotocin alone while none were noted in rats given nicotinamide alone or only the streptozotocin vehicle. The neoplasm's measured a few $\mathrm{mm}$ in diameter, were highly vascular and consisted of elements resembling normal islet cells. They were shown to secrete insulin, as evidenced by hypoglycemia, aldehyde-fuchsin-positive cytoplasmic granulation, and immunoreactive insulin concentrations of 230 to 350 units/g of tumor tissue.

The present communication confirms and extends the observations of Rakieten et al. [16] and character-

* Supported by a grant from the National Institutes of Health, No. A-2203

* Presented at the Eighth Congress of the International Diabetes Federation, Brussels, Belgium, June, 1973 izes the ultrastructural aspects of the induced islet cell tumors.

\section{Material and Methods}

Each of 41 male Holtzman rats with an average age of 70 days was injected intravenously with one dose of $50 \mathrm{mg} / \mathrm{kg}$ of streptozotocin (Upjohn Company, Kalamazoo, Michigan, U.9889, Lot 9164-VDV-136; $10 \mathrm{mg} / \mathrm{ml}$ in $0.025 \mathrm{M}$ citric acid in saline solution, $\mathrm{pH} 4.0$ ), preceded (by $10 \mathrm{~min}$ ) and followed (by $3 \mathrm{~h}$ ) by an intraperitoneal injection of $350 \mathrm{mg} / \mathrm{kg}$ of nicotinamide each $(35 \mathrm{mg} / \mathrm{ml}$ in saline solution).

In all rats, blood was withdrawn in the non-fasted state in biweekly or monthly intervals for glucose determinations, carried out by the Nelson-Somogyi method [15], and for serum insulin assays according to the procedure of Morgan and Lazarow $[13,14]$ with modifications as described [25].

The rats were anesthetized with ether and sacrificed 245 to 323 days after the injection of streptozotocin and nicotinamide. Their pancreases were removed at once and were divided into three portions. The first and smallest portion of the organ was immersed in cold $1 \%$ osmium tetroxide solution with added sucrose [3] and cut into blocks less than $1 \mathrm{~mm}$ [15]. The blocks were fixed for $90 \mathrm{~min}$ in ice-cold osmium tetroxide, rinsed briefly in distilled water, dehydrated and embedded in epoxy resin according to Luft [12]. Ultrathin sections were stained with uranyl acetate and lead citrate [17] and then viewed and photographed with an RCA EMU-3-G electron microscope. 
The second portion of pancreas was placed in Zenker-formaldehyde solution. Paraffin-embedded sections were cut at 3 microns and stained with hematoxylin and eosin, with a modified aldehyde-fuchsin trichrome stain [7] as previously described [10], and with potassium ferrocyanide for iron.

The third portion of the organ, approximately the same size as that used for light microscopy, was carefully freed from all extraneous tissue and then utilized for insulin radioimmunoassay studies, employing the two-antibody system of Lazarow and Morgan $[13,14]$ with modifications as recorded [25]. The insulin was extracted with acid alcohol. Three extractions with acid alcohol were done, the first employing ten times the determined pancreatic weight in milliliters of acid alcohol, and the last two using five times the pancreatic weight.

In animals with grossly visible pancreatic tumors, the neoplasms were always examined by electron microscopy. Those large enough to yield sufficient tissue were also utilized for light microscopic study and insulin immunoassay.

In all rats, the liver was also dissected, and portions of hepatic tissue were studied by light microscopy.

\section{Results \\ Gross Findings}

Pancreatic tumors measuring between 0.1 and 0.6 $\mathrm{cm}$ in greatest diameter were grossly visible in 16 rats (Fig. 1). The well delineated, rounded neoplasms were located in all parts of the organ without topographic predilection. Light microscopic examination subsequently uncovered small islet cell tumors in four additional animals; thus, islet cell tumors occurred in as many as 20 of the 41 rats $(49 \%)$. They were solitary in 15 and multiple (two or three tumors each) in the remaining five animals. The first two tumors were encountered in rats sacrificed 245 days after injection.

\section{Blood Glucose and Serum Insulin Assay}

There were no significant differences between the tumor-bearing rats and those without demonstrable neoplasms with regard to their average blood glucose and serum insulin levels, either during the course of the experiment or at its conclusion. For instance, the mean blood glucose value of the 21 tumor-free rats, calculated from measurements on blood obtained on their respective days of sacrifice or within the preceding two weeks, was $121 \mathrm{mg} / 100 \mathrm{ml}$, with a range from 95 to $152 \mathrm{mg} / 100 \mathrm{ml}$, whereas the mean serum insulin level amounted to 337 micro-units $/ \mathrm{ml}$ (range: $170-525$ ). For the 20 tumor-bearing animals, the corresponding figures were: blood glucose, $110(78-142) \mathrm{mg} / 100 \mathrm{ml}$; serum insulin concentration, $347(168-756)$ microunits $/ \mathrm{ml}$. There were also no statistically significant differences in these two parameters when the eight rats with the largest islet cell tumors $(0.2$ to $0.6 \mathrm{~cm}$ in greatest diameter) were matched against twelve rats with small tumors $(0.1 \mathrm{~cm}$ or less) or against the 21 tumor-free animals.

\section{Insulin Assay of Pancreatic Tissue}

In 37 rats the pancreatic tissue utilized for assay was free of grossly identifiable tumor. In these cases, insulin concentration ranged from zero to 2.68 units of insulin/g of wet weight, with a mean of 0.661 . In the four cases in which the tissue submitted for insulin assay contained portions of grossly visible tumors, the concentrations were $1.522,4.41,5.237$ and 10.37 units of insulin/g of wet weight pancreas, respectively, with a mean of 5.385. The difference between the two means is highly significant $(p<0.002)$.

\section{Light Microscopy.}

The smallest tumor detected by light microscopy was somewhat larger than a normal pancreatic islet (Fig. 2). In a section stained with the aldehyde-fuchsin triehrome method, it was composed of generally well granulated B cells that were larger than non-neoplastic B cells and contained vesicular nuclei with conspicuous, dark nucleoli (Fig. 3). Other small tumors were characterized by the trabecular arrangement of their cells (Fig. 4), and a few displayed focal round cell infiltrates. In all tumors, most cells were well granulated, although some stained more lightly than others (Fig. 3). Cells with the staining characteristics of $A$ or $D$ cells were not encountered. Iron-positive hemosiderin-containing cells, probably macrophages, were noted in many tumors, sometimes in form of large elusters. Occasionally, a proliferation of small ductular structures was noted, but none of these appeared to be related to a tumor.

No light microscopic lesions were detected in the livers of these animals. In particular, there were no neoplastic cells noted.

\section{Electron Microscopy}

In electron micrographs of normal rat islets, A, B and $\mathrm{D}$ cells were easily identified by their characteristic secretory granules. A cell granules displayed a more nearly homogeneous and darker matrix than did the secretory granules of $\mathrm{B}$ cells, and their limiting membranes were more closely applied to the secretory cores than was the case in the $B$ cell. The $D$ cells were characterized by densely packed, pale granules which had a finely granular or fibrillar texture and lacked any visible space between granular core and limiting membrane.

All examined tumors were composed of granulated cells, although the number and concentration of granules varied from case to case (Figs. 5-9). Tumor cells with few (Figs. 7 and 8) and with numerous granules (Fig. 5) were encountered. Not infrequently, the identifiable granules were smaller than usual (Figs. 7 and 8), but in all cases they appeared to be of the 

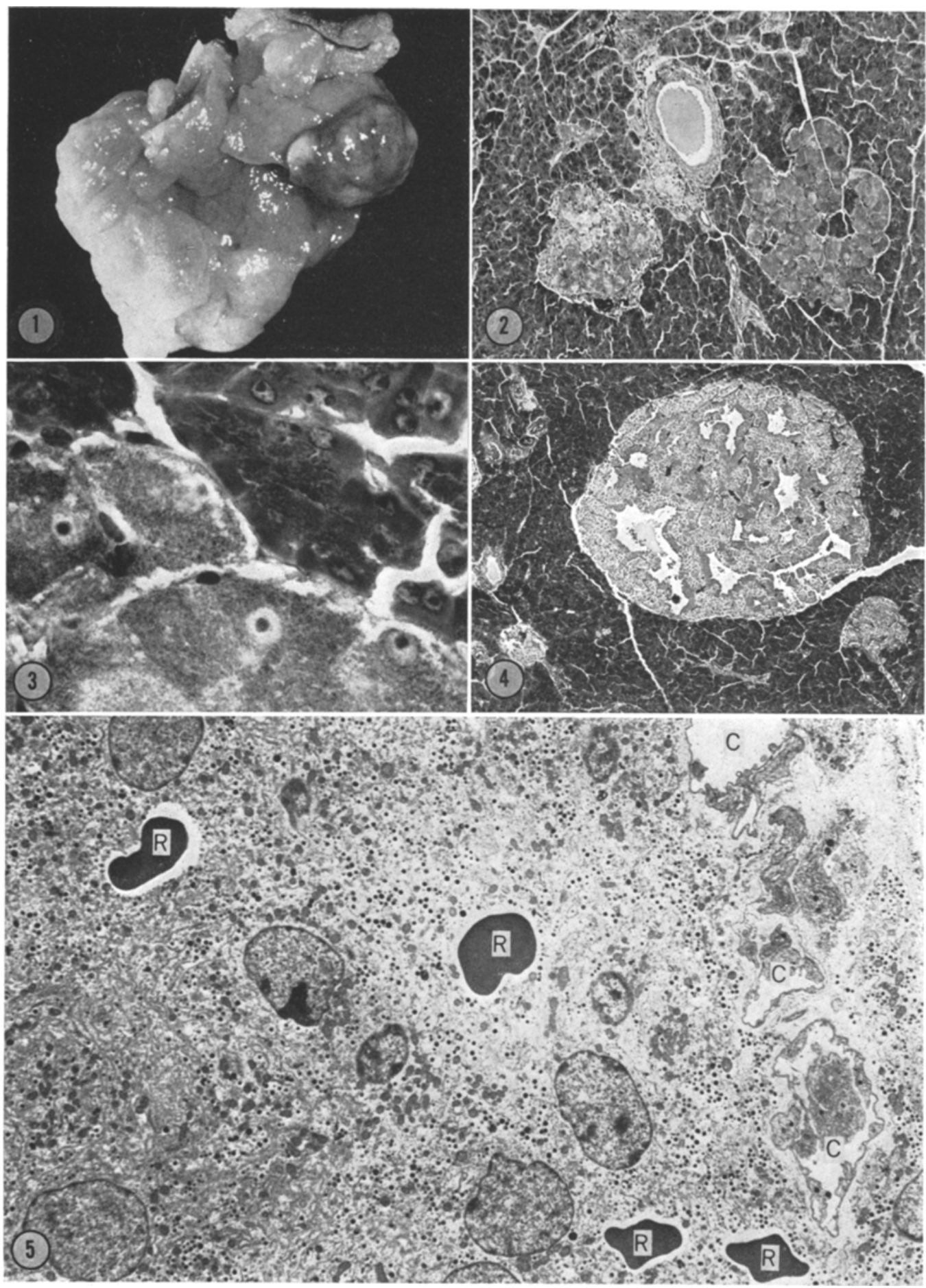

Figs. $1-5$. Portion of pancreas with rounded, well demarcated tumor measuring $0.6 \mathrm{~cm}$ in greatest diameter. $\times 4$. Normal islet (left) and smallest identified B cell tumor (right). Aldehyde-fuchsin trichrome stain. $\times 95$. Small B cell tumor of Fig. 2, at higher magnification. Most tumor cells appear well granulated and contain vesicular nuclei with distinct, dark nucleoli. Aldehyde-fuchsin trichrome stain. $\times 960$. Another small islet cell tumor which displays a trabecular arrangement of cells. Aldehyde-fuchsin trichrome stain. $\times 65$. Low power electron micrograph of islet cell tumor cells. Numerous secretory granules are present in these B cells. Several extravasated red blood cells (R) lie free in their eytoplasm. C-capillaries. $\times \mathbf{3 5 0 0}$ 
B cell variety. However, in one sparsely granulated tumor, cells with electron-dense, plump or elongate and often tear-drop-like granules were encountered, especially near the prominent Golgi apparatus (Fig. 8). Often, the granular membranes were so closely applied that they could not always be clearly identified. These cells are probably enterochromaffin cells (EC cells).

The cells of many of the tumors contained nuclei with distinctly enlarged, dark nucleoli (Figs. 6 and 7). In some, the units of the rough-surfaced endoplasmic reticulum appeared prominent and were cystically dilated (Fig. 7). Frequently, extravasated erythrocytes occupied portions of the eytoplasm of tumor cells (Figs. 5-7); they were not enclosed in a membrane, but were often surrounded by a clear space of shrinkage. Occasional necrosis of $\mathrm{B}$ cells, and their phagocytosis by macrophages, was observed (Fig. 9). In a few instances, tumor cell particles not delimited by a cell membrane were encountered in the lumina of capillaries.

\section{Discussion}

The present communication confirms that with the nicotinamide-streptozotocin regimen, as suggested by Rakieten et al. [16], pancreatic islet cell tumors can be induced in rats in a high percentage of cases. The absence of significant differences between the 20 rats with grossly or microscopically demonstrable islet cell tumors and the 21 tumor-free animals, with regard to their mean blood glucose and serum insulin levels, would seem to imply that the observed islet cell adenomas were "non-functioning", at least while they were being studied. In the series recorded by Rakieten et al. [16], rats with induced pancreatic neoplasms also failed to show a depression of their blood sugar levels before the twelfth month after the injection of nicotinamide and streptozotocin, and, as stated before, our rats were all sacrificed between the beginning of the ninth and the middle of the eleventh month of the experiment. In another group of similarly treated rats that has now been under observation in our laboratory for more than 15 months, there is evidence that hypoglycemia will eventually develop in tumor-carrying animals. The non-fasted state had been selected for blood glucose and insulin determinations because it was initially feared that some of the tumor-bearing animals might die from hypoglycemia if subjected to fasting.

The mean insulin concentration of the grossly tumorfree portions of pancreatic tissue in 37 cases amounted. to 0.661 units/g of wet weight, a mean very close to the figure of just below 500 milliunits/g obtained in untreated rats by Morgan and Lazarow [14]. In contrast, the mean pancreatic tissue concentration of insulin in the four cases with tumors was more than eight times as high. While the difference between the two means is significant at the 0.002 level of probability, very much higher insulin concentrations (250 to 350 units/g) have been recorded by Rakieten et al. for the tumors in their animals [16]. In our four cases, tumor tissue and extratumoral pancreas were processed together, and the obtained values can therefore be expected to be somewhat lower than those of the authors just mentioned, but there still remains an unexplained discrepancy of some magnitude between the two sets of values. In part, perhaps, this may be a matter of tumor cell maturation; the neoplasms in our animals were examined in an earlier stage, following their induction, than were those of Rakieten and coworkers [16], and they may not have produced large quantities of immunoassayable insulin. On the other hand, they appeared generally well granulated. We were unable to demonstrate a close correlation. between the degree of granulation in the histologic sections and the obtained tissue insulin concentrations.

Six of the 37 cases with no grossly visible tumor in the assayed tissue had pancreatic insulin concentrations of more than one unit/g of wet weight. Conceivably, these portions may have harbored microscopic tumors not detected by the naked eye. In fact, two of the six cases were among the four animals in whom small, grossly unsuspected islet cell neoplasms were seen in the tissue fragments examined by light microscopy. Also, five of the 20 animals with islet cell tumors $(25 \%)$ had multiple tumors. There is, then, a good chance that some of the assayed tissue portions did contain undetected neoplastic cells that may help explain the comparatively high pancreatic insulin concentrations in these few cases.

Ultrastructurally, all examined tumor cells appeared granulated even though the number of secretory granules varied from case to case, and cells with unusually small granules, probably indicating immaturity, were noted (Figs. 7 and 8). B cells with no, or few, or atypical secretory granules have frequently been observed in human islet cell tumors $[1,4-6,8,11,23$, 24]. Very rarely, granules resembling those of the A or $\mathrm{D}$ cell have been recorded in a few cells of certain human beta cell tumors [23], but cells with the ultrastructural characteristics of $A$ or $D$ cells were not discovered in any of the rat neoplasms examined by us. In contrast, occasional enterochromaffin cells (EC cells) were encountered in one of the tumors (Fig. 8). Such elements have also been described in human islet cell neoplasms [4].

In their recent evaluation of thirty human islet cell tumors, Creutzfeldt et al. [4] distinguished four tumor types based upon the nature of the secretory granules as seen in electron micrographs: type I, with typical B cell granules; type II, with typical and atypical B cell granules; type III, with atypical granules only, and type IV, virtually agranular tumors. Most of these human neoplasms were of types I and II. In our own material, no tumors of types III or IV were found. Of the 27 islet cell adenomas encountered in 20 of 41 examined rats, 22 corresponded to type $I$ and the remaining five to type II. 


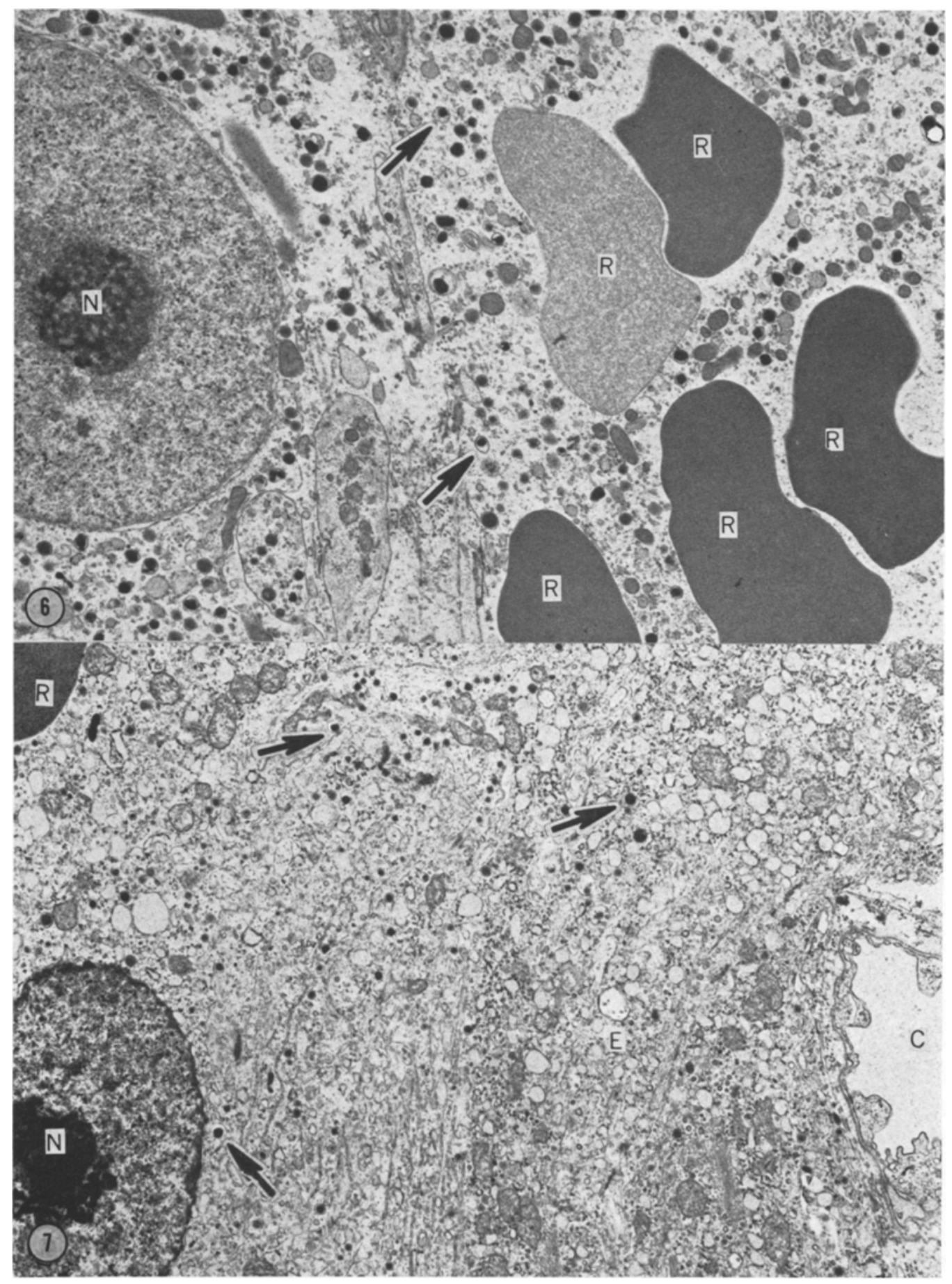

Figs. 6-7. Extravasated erythrocytes (R), varying in electron density, occupy portions of the B cell cytoplasm of another tumor. Many secretory granules are present (arrows). The nucleus of a neighboring neoplastic $B$ cell contains a large nucleolus $(\mathrm{N}) . \times 10500$. The cells of this tumor contain unusually small, electron-dense secretory granules (arrows), considerably dilated units of the endoplasmic reticulum ( $\mathrm{E}$ ), a prominent, dark nucleolus (N), and an extravasated erythrocyte (R). C-capillary. $\times 10500$ 


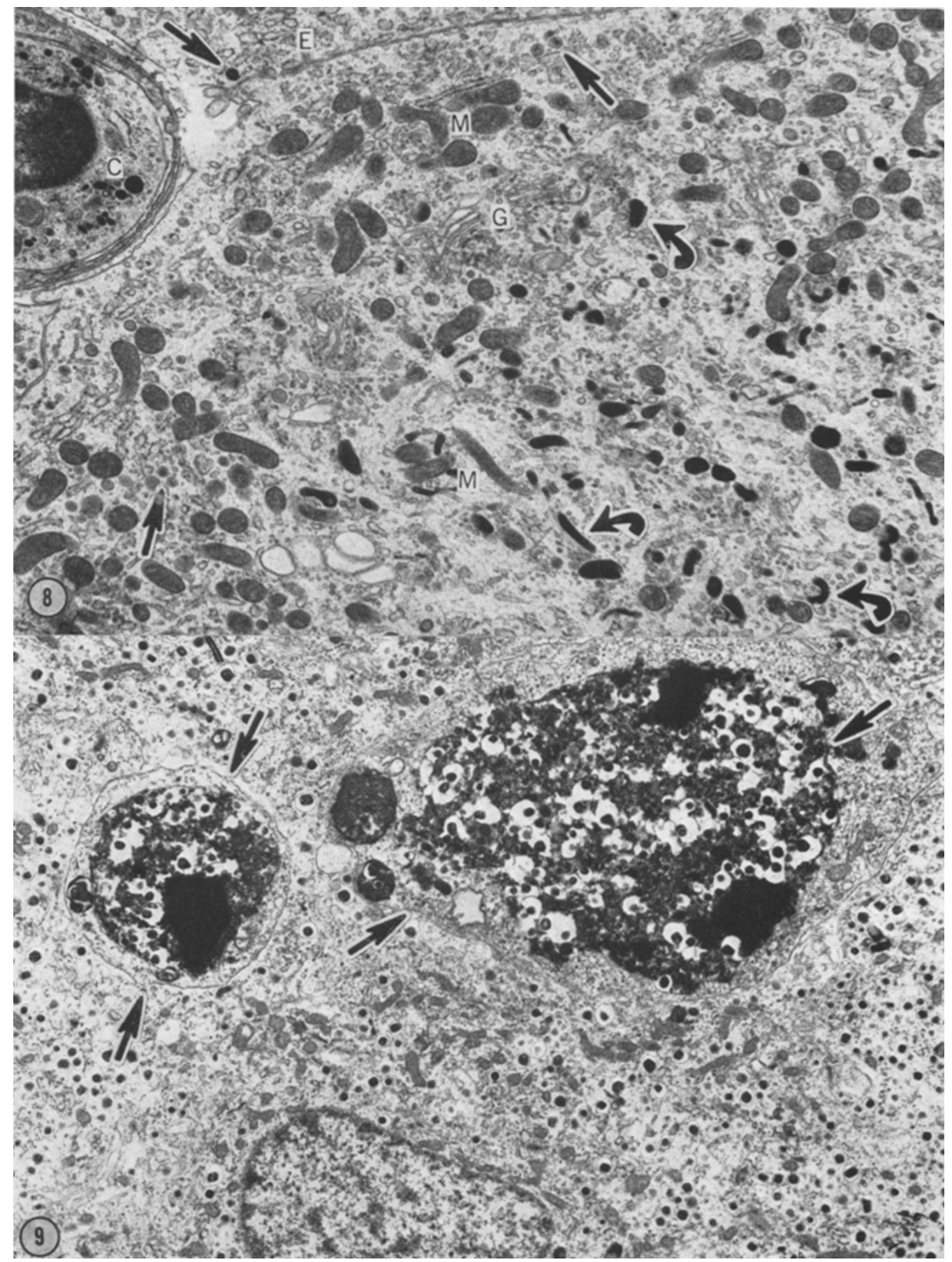

Figs. 8-9. Portions of cells from another tumor. Some small, round secretory granules (straight arrows) are present, but other granules (curved arrows) are elongate, teardrop-like, or less regular. A few of the mitoehondria (M) appear distorted. C-capillary; E-endoplasmic reticulum; G-Golgi complex. X 13875. Macrophages having engulfed several membrane-enclosed necrotic B cell particles (arrows) in which the secretory granules are still clearly visible. $\times 10500$ 
Often found free in the cytoplasm of tumor cells were extravasated erythrocytes (Figs. 5-7), and hemosiderin-laden cells, probably macrophages, were noted in many of the islet cell tumors. Also, occasional tumor cell fragments were observed within the lumina of capillaries. All of these features were absent in nonneoplastic islet tissue. They are probably indicative of a comparatively greater degree of fragility of the tumor tissue and its supporting capillary network. The occasional occurrence of inflammatory cell nests in some neoplasms is felt to be a reactive phenomenon related to foci of tumor cell necrosis. The presence of tumor cell particles within the lumina of capillaries is possibly an artefact; it appears unlikely that this feature indicates invasive growth. Whether some of these tumors give rise to metastases will be examined more closely in a subsequent long-term experiment.

Spontaneous tumors of the pancreas, especially the islet cell, are rare in rats and other laboratory animals [18]. Islet cell neoplasms have previously been induced in this species by irradiation [2] and after the injection of certain plant-derived pyrrolizidine alkaloids [20]. With the streptozotocin-nicotinamide combination devised by Rakieten et al. [16] and employed in this laboratory, a distinetly greater percentage of rats have developed islet cell tumors than with any other regimen tried thus far. In comparison to the streptozotocinnicotinamide-induced neoplasm, the metastasizing, transplantable islet cell tumor of the Syrian hamster, as described in recent years, is characterized by a much lower mean insulin content $(0.024$ and 0.072 units $/ g$ of wet weight) $[9,22]$ and by the almost total absence of identifiable typical $B$ cell granules, at least at the ultrastructural level [21]. Nevertheless, these tumors do induce hypoglycemia upon fasting, and high fasting plasma insulin levels are demonstrable [22]. Apparently, then, the transplantable islet cell tumors of the hamster secrete much insulin, but are incapable of storing it; in contrast, the generally well granulated islet cell tumors of the rat store insulin in sizeable quantities, but appear to secrete only little, at least during the initial nine or ten months after tumor induction. A defective storage capacity for insulin has also been demonstrated for many of the 30 human islet cell neoplasms recently analyzed by Creutzfeldt and co-workers [4].

The mechanism through which nicotinamide and streptozotocin exert their roles as co-carcinogens in the development of islet cell tumors remains unexplained on the basis of a morphologic study such as this one. 'The histogenesis of these neoplasms is also not fully understood. In their recent study of human B cell tumors, Suzuki and Matsuyama [23] have suggested that type 1 tumors (composed of typical, well granulated $B$ cells) originate from the $B$ cells of the islets of Langerhans, whereas the elements of type 2 tumors (containing cells with no or with a few immature B, A or D granules) resemble ductular cells and derive from them. In the rats under discussion, all observed tumors, even the smallest ones detected only by light microscopy, were well circumscribed and were surrounded by acinar tissue. They failed to display any morphologically obvious histogenetic relationship to either pancreatic ducts or non-neoplastic islets. On the other hand, the cells of some of the adenomas themselves were arranged in duct- or gland-like structures (Fig. 4), a feature not infrequently observed in ontoand phylogenetically immature islets as well as in human islet cell tumors $[4,5]$.

Acknowledgements. The authors are indebted to Dr. William E. Dulin of The Upjohn Company for providing them with the streptozotocin, to Mrs. Celina Mitgang, Miss Rochelle Schranz, and Mr. Zoran Dordevie for valuable technical assistance, to Mr. Herbert A. Fischler, Chief Medical Photographer, for preparing the illustrations, and to Mrs. Renee Brenner for typing and editing the manuscript.

\section{References}

1. Bencosme, S.A., Allen, R.A., Latta, H.: Functioning pancreatic islet cell tumors studied electron microscopically. Amer. J. Path. 42, 1-10 (1963)

2. Boschetti, A.E., Moloney, W.C.: Observations on pancreatic islet cell and other radiation-induced tumors in the rat. Lab. Invest. 15, $565-\mathbf{5 7 5}(\mathbf{1 9 6 6 )}$

3. Caulfield, J.B.: Effects of varying the vehicle for $\mathrm{OsO}_{4}$ in tissue fixation. J. biophys. biochem. Cytol. 3, $827-830(1957)$

4. Creutzfeldt, W., Arnold, R., Creutzieldt, C., Deuticke, U., Frerichs, H., Track, N.S.: Biochemical and morphological investigations of 30 human insulinomas: Correlation between the tumour content of insulin and proinsulin-like components and the histological and ultrastructural appearance. Diabetologia 9, 217-231 (1973)

5. Frantz, V.K.: Tumors of the Pancreas. Atlas of Tumor Pathology, Section VII, Fascicles 27 and 28, pp. 82-123. Washington, D.C.: Armed Forces Institute of Pathology 1959

6. Georgsson, G., Wessel, W.: Vergleichende elektronenmikroskopische Untersuchungen normaler menschlicher Pankreasinseln und eines hormonellaktiven Inselzell-Carcinoms mit Hyperinsulinismus. Z. Krebsforsch. 69, 70-86 (1967)

7. Gomori, G.: Aldehyde-fuchsin: New stain for elastic tissue. Amer. J. clin. Path. 20, 665-666 (1950)

8. Greider, M.H., Elliott, D.W.: Electron microscopy of human pancreatic tumors of islet cell origin. Amer. J. Path. 44, 663-678 (1964)

9. Grillo, T.A.I., Whitty, A.J., Kirkman, H, Foa, P.P., Kobernick, S.D.: Biological properties of a transplantable islet-cell tumor of the golden hamster. I. Histology and histochemistry. Diabetes 16, 409-414 (1967)

10. Lazarus, S.S., Volk, B.W.: The pancreas in human and experimental diabetes. pp. 257-267. New York: Grune \& Stratton, Inc. 1962

11. Lazarus, S.S., Volk, B.W.: Histochemical and electron microscopic studies of a functioning insulinoma. Lab. Invest. 11, 1279-1294 (1962)

12. Luft, J.H.: Improvements in epoxy resin embedding methods. J. biophys. biochem. Cytol. 9, 409-414 (1961)

13. Morgan, C.R., Lazarow, A.: Immunoassay of insulin: Two antibody system: Plasma insulin levels of normal, subdiabetic and diabetic rats. Diabetes 12, 115-126 (1963) 
14. Morgan, C.R., Lazarow, A.: Immunoassay of pancreatic and plasma insulin following alloxan injection of rats. Diabetes 14, 669-671 (1965)

15. Nelson, N.: Photometric adaption of Somogyi method for determination of glucose. J. biol. Chem. 153, $375-380$ (1944)

16. Rakieten, N., Gordon, B.S., Beaty, A., Cooney, D.A., Davis, R.D., Schein, P.S.: Pancreatic islet cell tumors produced by the combined action of streptozotocin and nicotinamide (35561). Proc. Soc. exp. Biol. 137, $280-273(1971)$

17. Reynolds, E.S.: The use of lead citrate at high $\mathrm{pH}$ as an electron-opaque stain in electron microscopy. J. Cell Biol. 17, 208-212 (1963)

18. Rowlatt, U., Roe, F.J.C.: Epithelial tumors of the rat pancreas. J. Nat. Cancer Inst. 39, 18-32 (1967)

19. Schein, P.S., Cooney, D.A., Vernon, M.L.: The use of nicotinamide to modify the toxicity of streptozotocin diabetes without loss of anti-tumor activity. Cancer Res. 27, 2324-2332 (1967)

20. Schoental, R., Fowler, M.E., Coady, A.: Islet cell tumors of the pancreas found in rats given pyrrolizidine alkaloids from Amsinckia intermedia Fisch and Mey and from Heliotropium supinum L. Cancer Res. 30, 2127-2131 (1970)

21. Simar, L.J., Sodoyez, J.C., Grillo, T.A.I., Nagano, T., Lefebre, P.F., Foa, P.P.: Biological properties of a transplantable islet-cell tumor of the golden hamster. IIJ. Electron microscopic studies. Diabetes 17, 582$587(1968)$

22. Sodoyez, J.C., Luyckx, A. S., Lefèbre, P.J. : Biological properties of a transplantable islet-cell tumor of the golden hamster. II. Insulin content of the tumor and some metabolic characteristics of the tumor-bearing animals. Diabetes 16, 415-417 (1967)

23. Suzuki, H., Matsuyama, M.: Ultrastructure of functioning beta cell tumors of the pancreatic islets. Cancer 28, 1302-1313 (1971)

24. Toker, C.: Observations on the ultrastructure of a metastasizing beta cell islet tumor. Diabetes 16, 800-803 (1967)

25. Volk, B.W., Wellmann, K. F., Lazarus, S. S., Brancato, P.: Beta cell morphology and insulin immunoassay in long-term subdiabetic rabbits. Arch. Path. 88, 413$422(1969)$

B.W. Volk, M.D.

Isaac Albert Research Institute

of the Kingsbrook Jewish Medical Center

Rutland Rd and East 49 th Street

Brooklyn

New York 11203

USA 